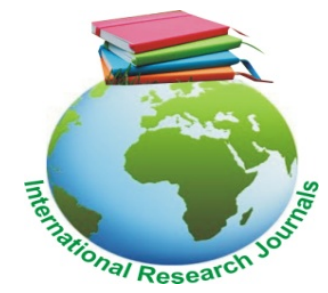

African Journal of Food Science and Technology (ISSN: 2141-5455) Vol. 6(7) pp. 185-193, November, 2015

DOI: http:/dx.doi.org/10.14303/ajfst.2015.045

Available online @http://www.interesjournals.org/AJFST

Copyright (C2015 International Research Journals

Full Length Research Paper

\title{
Effect of dryer parameters on the drying characteristics and quality of cassava flour
}

\author{
Lateef Ayodele Sanni, Eniyome Sampson Ugoso, Michael Oladimeji Faborode \\ Department of Agricultural and Environmental Engineering Obafemi Awolowo University, Ile-Ife, Nigeria. \\ Corresponding author: Idsanni@yahoo.com; +234 8062756778.
}

\begin{abstract}
In this study a conductive rotary dryer (CRD) was developed for the drying of pulverized cassava meal with a view to mechanizing the traditional sun-drying method. The effects of four parameters of the dryer were investigated and optimized using the Taguchi technique. Drum temperature had the most significant effect on the swelling index of the cassava meal with signal-to-noise ratio difference of 3.16. A swelling index of 1.02 was predicted for cassava meal dried at drum temperature of $140^{\circ} \mathrm{C}$, vapor extraction rate of $0.03 \mathrm{~m}^{3} / \mathrm{sand} 8 \mathrm{~kg}$ of wet cassava meal per batch. The moisture content of the cassava meal decreased from $45 \%$ to $10 \%$ (wet basis) in an average of 44 minutes and the proximate composition of the dried cassava meal met the standard specification recommended for cassava flour. The application of the CRD was better than traditional sun drying and its injection into the cassava processing industry can contribute to agro-industrial growth in cassava producing countries of Africa.
\end{abstract}

Key words: conductive rotary dryer, parameters, cassava flour, drying characteristics

\section{INTRODUCTION}

Cassava (Manihotesculenta Crantz.) is a major food crop grown in many tropical parts of the world. It supplies about $70 \%$ of the daily calorie requirement for over 50 million people in Nigeria (Oluwoleet al., 2004). It is widely reported that over 500 million people around the world derive their daily carbohydrate intake from cassava (Cock, 1985; FAO, 2000; Udofia et al., 2010). Nigeria ranks as the largest producer of cassava in the world with an estimated annual production of between 34 and 37 million metric tons in 2002 (FAO, 2004, 2006). Nigeria currently produces about 40 million metric tons of cassava annually, but is yet to be a major player in the global cassava market (Babatunde 2012). Estimate of cassava use in Nigeria shows that about $84 \%$ of annual production is processed into various foods for local consumption (Phillips et al., 2004). Among many of the staple foodstuffs produced from cassava, gari (fermented and gelatinized cassava meal) and fermented cassava flour (lafunor fufu) are the most widely consumed (Oluwoleet al., 2004).

High quality cassava flour (HQCF) is fine, unfermented, odorless and bland flour with no gluten
(USAID, 2010). HQCF has contributed to cassava industrial revolution in Nigeria and Ghana with enormous potentials in other countries in West Africa (Sanni et al., 2009). The product has been found to be suitable for making cakes, cookies, doughnuts and bread. It also serves as an industrial raw material for textiles, plywood, paper and pharmaceutical industries (Dziedzoave et al., 2006). HQCF can be produced by a process similar to gari production. According to Nwekeet al.(2002) gariis produced by washing and peeling freshly harvested tubers of cassava. The peeled tubers are grated into a watery pulp andleft to ferment in perforated polyethylene bags for a few days, after which it is dewatered by pressing. The pressed cake of about $45-50 \%$ moisture content is sieved and toasted on a hot frying pan during which the starch granules gelatinize. The end product is a ready-to-eat, white or yellowish meal popularly known as gari. For HQCF the grated mash is pressed immediately to prevent fermentation and the pulverized wet meal is dried under a relatively low temperature to prevent gelatinization of the starch granules. The dried product is then milled to produce fine flour. At the end of production 
both gariand HQCF should have a maximum moisture content of $11 \%$ wet basis (CIGR, 1999; SON, 2004).

\section{Challenges with drying of wet cassava meal}

Drying of the wet cassava meal to produce HQCF constitute the most critical processing operation. Due to lack of appropriate technology for drying, most local processors resort to the use of crude and unhygienic traditional methods, which affect the quality of the product (Ajibola et al., 1998). Open-air sun-drying of wet cassava meal is widely practiced and efforts to mechanize the drying of wet cassava meal have been mainly targeted towards gari production. The flash dryer was adapted for drying wet cassava meal for HQCF production on a commercial scale but with little success, largely due to high ownership and operational costs (IITA, 2005). A conductive rotary dryer (CRD) was designed and fabricated in the Department of Agricultural and Environmental Engineering, Obafemi Awolowo University, lle-Ife, for the rapid drying of wet cassava meal for gari and HQCF production (Sanni, 2014; Sanni et al., 2015). The CRD operational parameters such as drum temperature, vapor extraction rate, shape of flight were variable and the CRD was successfully used to dry wet cassava meal to safe moisture content. However the effect of the dryer parameters on the drying characteristics and quality of HQCF needed to be investigated so that improvement in its design and upgrading can be achieved.

\section{Quality characteristic of dried cassava meal}

Swelling Index (SI) of a granular food material is the ratio of its final volume when soaked in distilled water to its initial dry volume (Ajibola et al., 1987). Studies have shown that swelling index (SI) of dried cassava mealis a quality characteristicwhich measures its degree of gelatinization and dryness (Owuamanamet al., 2010). When soaked in water, gari (gelatinized cassava meal)is expected to swell beyond its initial volume and previous works have shown that the swelling index of gari can vary between 2.0 and 4.0 depending on the cassava cultivar and processing method used (Irtwange and Achimba, 2009; Apea-Bah et al., 2009). According to Sanni et al. (2015), a dried and gelatinized cassava meal (e.g. gari) has higher values of swelling index and a dried but less gelatinized cassava meal (e.g. HQCF) has lower values of swelling index.

\section{Description of the conductive rotary dryer (CRD)}

The CRD prototype developed by Sanni (2014) is basically a stainless cylindrical drum whose external surface is heated directly by electrical heating elements. The drum is horizontally supported on four small rollers and rotates at a low speed while its surface heats up simultaneously. One or two flights each having the same length with the drumcan be located on the inner surface of the drum for lifting and dispersing the wet cassava meal to be dried. The wet cassava meal of predetermined weight and moisture content is introduced into the drum from one end through a hopper and a screw conveyor, and by means of the internal flights and rotation of the drum, the cassava meal is intermittently lifted and dispersed or 'fluidized' in a cascading motion. The lifting and dispersion of the cassava meal helps to increase the surface area of individual granules exposed to the drying air thereby increasing the rate of drying (Mujumdar, 2006). By conduction the wet cassava meal in contact with the hot drum surface absorbs the sensible heat required for vaporization, and by means of aperforated and cylindrical air duct and the action of a centrifugal fan, the vapor from the wet cassava meal is continuously extracted from the drying chamber by suction. The rotating drum is entirely enclosed by an insulated wall lagged with fiber glass to prevent heat loss. At the end of drying, the cassava meal is discharged from the drum by gravity through a trough located directly below it. Compared to the popular sun-drying or open-air toasting methods, hygiene-sensitive foods such as HQCF and gari are completely protected from contamination. Figure 1 shows the orthographic drawing of the section through the longitudinal axis of the CRD. Compared to the flash dryer, the design of the CRD is simple because the electrical heaters can be replaced with cheaper sources of energy such as cooking gas, charcoal or bio-gas.

\section{MATERIALS AND METHODS}

\section{MATERIALS}

The materials and equipment used for the investigation are the conductive rotary dryer used for all the drying experiments, freshly harvested cassava tubers of the variety TMS 30572, motorized grater for milling cassava tubers and vertical screw press for dewatering grated cassava mash. A manually woven screen mesh was used to pulverize and sieve the pressed cassava cake. All other experiments were carried out in the laboratories of the Department of Agricultural and Environmental Engineering and Animal Science Department of Obafemi Awolowo University, lle-Ife, Nigeria.

\section{Experimental Methods}

\section{Experimental design}

According to the method used by (Akhyaret al., 2008), and Esme (2009), the Taguchi statistical method and 

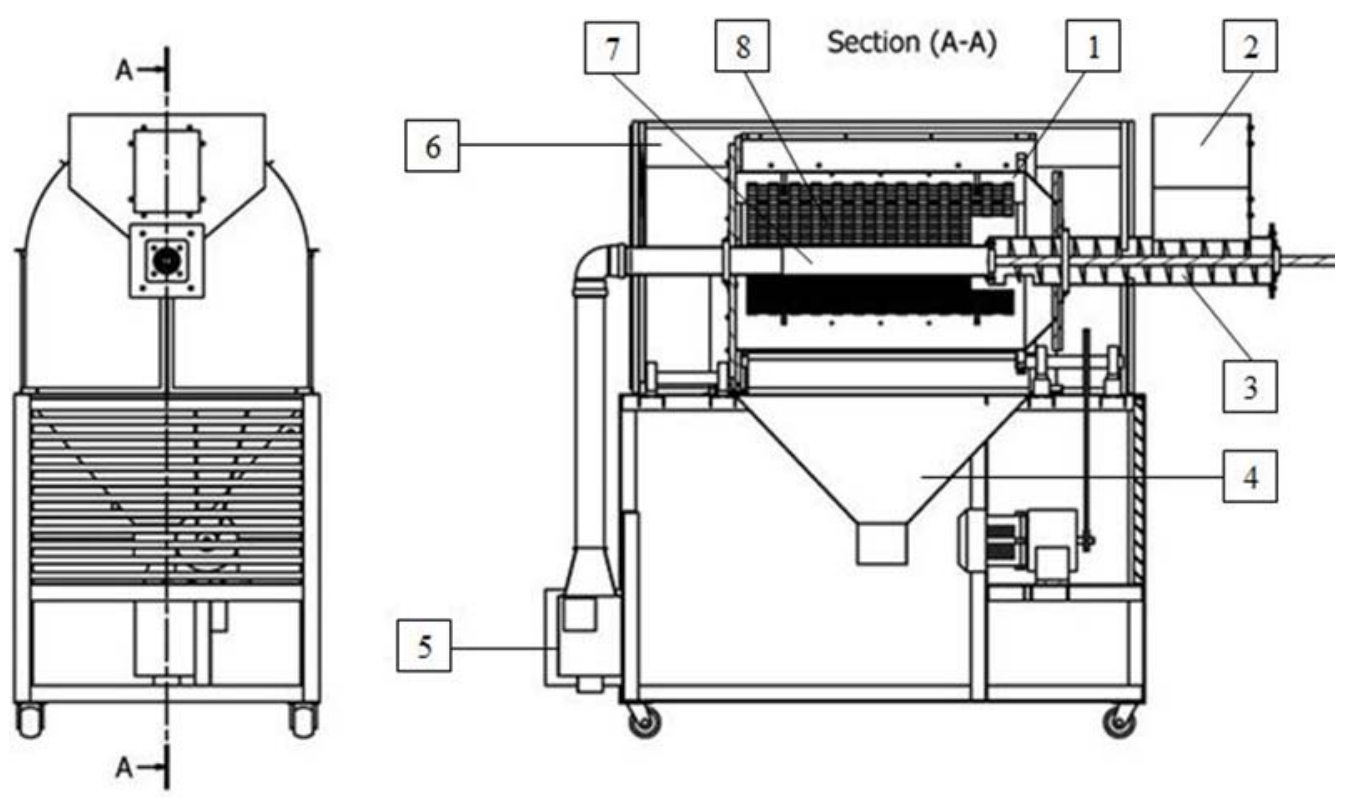

Figure 1. Sectional drawing of the conductive rotary dryer 1-rotary drum; 2-feed hopper; 3-feed auger; 4-discharge trough; 5-centrifugal fan; 6-insulated housing; 7vapour extraction duct; 8-flight

Table 1. Levels of dryer parameters

\begin{tabular}{ccccc}
\hline Symbol & Process Parameters & Unit & Level 1 & Level 2 \\
\hline A & Flight shape & - & Straight & Curved \\
B & Batch quantity & $\mathrm{kg}$ & 5 & 8 \\
C & Vapour extraction rate & $\mathrm{m}^{3} / \mathrm{s}$ & 0.0075 & 0.03 \\
D & Drum temperature & ${ }^{\circ} \mathrm{C}$ & 140 & 190 \\
\hline
\end{tabular}

analysis of variance (ANOVA) were used to study the effects offour process parameters namely, shape of flight in the drum, quantity of wet cassava meal fed into the drying chamber $(\mathrm{kg})$, vapor extraction rate from the drying chamber $\left(\mathrm{m}^{3} / \mathrm{s}\right)$ and drum temperature $\left({ }^{0} \mathrm{C}\right)$. Each parameter was varied at two levels as presented in Table 1.

The L8 orthogonal array experimental design was chosenfrom the Taguchi array selector and eightdrying experimentswere run in the CRD to study the effect of the four parameters on the drying characteristics and quality (swelling index) of cassava flour produced. The L8 experimental design was chosen because the degree of freedom (DF) of the 8 experiments $\left(D_{\text {experiments }}=7\right)$ is greater than that of the four dryer parameters varied at two levels each $\left(D_{\text {dryer parameters }}=4\right)$. The experimental design used for the study is presented in Table 2.

The Taguchi loss function was also determined according to the method used by Kamaruddin et al.(2004) and Esme (2009). The relationship between the swelling index and quality of dried cassava meal to be used for HQCF is that,the lowerits swelling index the better because minimum gelatinization of starch granules is desired. Therefore the Taguchi loss function which is equivalent to the mean squared deviation (MSD) was based on the-lower-the-better criterion and the following mathematical expression was used to calculate the corresponding signal-to-noise ratio $(\mathrm{S} / \mathrm{N})$ for each experiment:

$$
\left(\frac{g}{N}\right)_{t}=-10 \log \left(\sum_{k=1}^{n} \frac{x^{n}}{n}\right)
$$

$\left(\frac{s}{w}\right)_{t}=$ signal-to-noise ratio of the swelling index of cassava meal from theit ${ }^{\text {th }}$ experiment

$n=$ replicate(s)of swelling index from each experiment

$y_{i}=$ swelling index of the dried cassava meal from the $i^{\text {th }}$ experiment

The S/N ratio was analyzed by finding the average of the $\mathrm{S} / \mathrm{N}$ ratio for each of the levels under each parameter. The level with the higher S/N ratio was chosen as the optimum level at which the dryer parameter should be operated. The corresponding value of swelling index at the optimum level for each parameter was similarly calculated and recorded. The regression expression of 
Table 2. Experimental design based on L8 orthogonal array

\begin{tabular}{ccccc}
\hline $\begin{array}{c}\text { Number } \\
\text { of Experiment }\end{array}$ & \multicolumn{4}{c}{ CRD Parameters } \\
\cline { 2 - 5 } & $\begin{array}{cccc}\text { A } \\
\text { Flight } \\
\text { shape }\end{array}$ & $\begin{array}{c}\text { Batch } \\
\text { quantity } \\
\mathbf{( k g )}\end{array}$ & $\begin{array}{c}\text { Vapor } \\
\text { extraction } \\
\text { rate } \\
\left(\mathbf{m}^{3} / \mathbf{s}\right)\end{array}$ & $\begin{array}{c}\text { Drum } \\
\text { temperature } \\
\left({ }^{\circ} \mathbf{C}\right)\end{array}$ \\
\hline 1 & Straight & 5 & 0.0075 & 140 \\
2 & Straight & 5 & 0.0075 & 190 \\
3 & Straight & 8 & 0.03 & 140 \\
4 & Straight & 8 & 0.03 & 190 \\
5 & Curved & 5 & 0.03 & 140 \\
6 & Curved & 5 & 0.03 & 190 \\
7 & Curved & 8 & 0.0075 & 140 \\
8 & Curved & 8 & 0.0075 & 190 \\
\hline
\end{tabular}

Equation 2 was used to predict the swelling index of the dried cassava meal if the CRD was operated at the optimum levels of the parameters.

$y_{\text {opt }}=\bar{y}_{m}+\left(y_{\text {Aopt }}-\bar{y}_{m}\right)+\left(y_{\text {bopt }}-\bar{y}_{m}\right)+\left(y_{\text {copt }}-\bar{y}_{m}\right)+\left(y_{\text {copt }}-\bar{y}_{m}\right)$

$y_{\text {opt }}=$ predicted optimum value of swelling index

$\overline{\bar{y}}_{r u}=$ grand mean of swelling index

$\bar{y}_{\text {Afor: }}=$ average value of swelling indexat optimum level of flight shape

$\bar{y}_{\text {Bopt }}=$ average value of swelling index at optimum level of batch quantity

$\bar{y}_{\text {smpr }}=$ average value of swelling index at optimum level of vapor extraction rate

$\bar{y}_{D o p t}=$ average value of swelling index at optimum level of drum temperature

2.2.2 Production of wet cassava meal for drying experiments

Similar to the method used by Ademiluyi et al. (2010) fresh cassava tubers of the variety TMS 30572 were harvested from the Teaching and Research Farm of the Obafemi Awolowo University, Ile-Ife. The cassava tubers were washed, peeled and milled in a motorized grater. The grated mash was collected in perforated polyethylene bags and placed under a vertical screw press for 2 hours to be dewatered. The pressed cassava cakes were pulverized and sifted into a uniform meal of 2 to $3 \mathrm{~mm}$ particle size, in readiness for the drying experiments.

\section{Determination of initial and final moisture content of cassava meal}

The initial moisture and final content (wet basis) of the cassava meal wererespectively determined before and after drying each batch in the CRD for 35 minutes. The standard oven-drying method described by ASAE (1983) was used and Equation 3 was used to calculate the moisture content of the wet cassava meal:

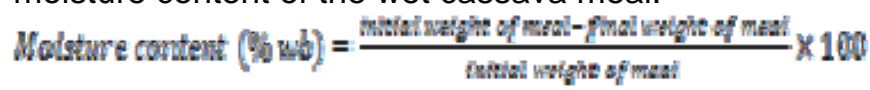

(3)

\section{Drying characteristics of cassava meal in the CRD}

Six fractional experiments were carried out to determine the effects of drum temperature, vapor extraction rate and batch quantity on the drying characteristicsof cassava meal in the CRD. The six experiments were run at different combinations ofthe parameter levels as presented in Table 3.

Other parameters such as drum speed, shape and number of flights were kept constant. Each experiment was run for 60 minutes until the there was no more moisture in the cassava meal. During each experiment samples were taken every 5 minutes and used to determine the moisture content of the cassava meal in the dryer.Moisture content of each sample was determined using the ASAE (1983) standard with slight modification. From each sample, $20 \mathrm{~g}$ of cassava meal was put in a drying can of known weight and placed in the oven at $105^{\circ} \mathrm{C}$ for 5 hours until equilibrium was 
Table 3. Fractional experimental design for drying characteristics of cassava meal in the CRD

\begin{tabular}{llll}
\hline \multirow{2}{*}{$\begin{array}{l}\text { Number } \\
\text { of Experiment }\end{array}$} & $\mathrm{B}$ & $\mathrm{C}$ & $\mathrm{D}$ \\
\cline { 2 - 4 } & $\begin{array}{l}\text { Batch } \\
\text { quantity } \\
(\mathrm{kg})\end{array}$ & $\begin{array}{l}\text { Vapor } \\
\text { extraction rate } \\
\left(\mathrm{m}^{3} / \mathrm{s}\right)\end{array}$ & $\begin{array}{l}\text { Drum } \\
\text { temperature } \\
\left({ }^{\circ} \mathrm{C}\right)\end{array}$ \\
\hline 1 & 5 & 0.0075 & 140 \\
2 & 5 & 0.03 & 200 \\
3 & 8 & 0.03 & 140 \\
4 & 8 & 0.0075 & 140 \\
5 & 8 & 0.03 & 200 \\
6 & 5 & 0.0075 & 200 \\
\hline
\end{tabular}

Table 4. S/N responses to swelling index of cassava flour

\begin{tabular}{llllll}
\hline $\begin{array}{l}\text { Exp. } \\
\text { No. }\end{array}$ & $\begin{array}{l}\text { Parameter } \\
\text { Levels }\end{array}$ & $\begin{array}{l}\text { Initial } \\
\text { moisture } \\
\text { content } \\
(\%)\end{array}$ & $\begin{array}{l}\text { Final } \\
\text { Moisture } \\
\text { content } \\
(\%)\end{array}$ & $\begin{array}{l}\text { Swelling } \\
\text { index }\end{array}$ & $\begin{array}{l}\text { S/N } \\
\text { ratio }\end{array}$ \\
\hline 1 & A B C D & 45 & 16.12 & 1.72 & -4.71 \\
2 & 1111 & 45 & 6.77 & 2.89 & -9.22 \\
3 & 1112 & 45 & 19.79 & 1.00 & 0 \\
4 & 1221 & 45 & 9.43 & 1.94 & -5.76 \\
5 & 1222 & 45 & 16.07 & 1.67 & -4.45 \\
6 & 2121 & 45 & 7.24 & 2.06 & -6.28 \\
7 & 2211 & 45 & 14.98 & 1.61 & -4.14 \\
8 & 2212 & 45 & 8.53 & 1.72 & -4.71 \\
\hline
\end{tabular}

reached. The weight of the bonedry sample wasmeasured and recorded. The moisture content (\% wet basis) for each sample was calculated using Equation 3.The values of moisture content were used to plot the drying curves for the six experiments. For each parameter the averages of the moisture contents at its lower and higher levels were calculated and used to plot low and high level curves. The hysteresis between the two curves for each parameter were usedto analyze the effect of each parameter on drying characteristic of cassava meal in the CRD.

\section{Determination of swelling index}

At the end of each drying experiment outlined in Table 2, the batch of dried cassava meal was evacuated from the CRD and allowed to cool. The swelling index (SI) of each batch was determined by the method used by Apea-Bah et al. (2009) with slight modification. Initial volume of 18 $\mathrm{ml}$ of the dried cassava meal was introduced into a 100 $\mathrm{ml}$ measuring cylinder. The measuring cylinder was filled with distilled water to the $100 \mathrm{ml}$ mark and shaken for proper mixture. The solution was allowed to settle for 5 minutes before shaking again. The intermittent shaking and settling lasted for 20 minutes and after the last settlement, the final volume of the cassava meal was recorded. The swelling index was calculated as:
SWelling Index $=\frac{\text { Final volume of garzava meal in waten }}{\text { Inftilal dry volume }}$

(4)

\section{Proximate analysis of HQCF}

At the end of each drying experiment in the CRD, samples were taken from each batch of the dried cassava meal for proximate analysis. The standard method recommended by AOAC (1987) was used to determine the moisture content (\%), ash content (\%), crude fiber content (\%), ether extract (\%) and crude protein content (\%) of the samples. The proximate composition of the dried cassava meal was compared with SON (2004) specifications for HQCF.

\section{RESULTS AND DISCUSSION}

The final moisture content (\% wet basis), swelling index and corresponding $\mathrm{S} / \mathrm{N}$ ratio which was derived from Equation (1) for the cassava meal from each experiment are summarized in Table 4.Only cassava meal from Experiments 2, 4, 6 and 8 had moisture content below the recommended $11 \%$.The cassava meal from Experiment 8 which had a moisture content of $8.53 \%$ and swelling index of 1.72 was used for proximate analysis. Table 5 shows that the proximate composition 
Table 5. Comparison of proximate compositions

\begin{tabular}{|c|c|c|c|c|c|c|}
\hline & \multicolumn{6}{|c|}{ Proximate composition of cassava flour } \\
\hline & $\begin{array}{l}\text { Moisture } \\
\text { content }\end{array}$ & $\begin{array}{l}\text { Carbohyd- } \\
\text { rate }\end{array}$ & Ash & Crude fiber & $\begin{array}{l}\text { Crude } \\
\text { protein }\end{array}$ & $\begin{array}{l}\text { Ether } \\
\text { extract }\end{array}$ \\
\hline *SON standard & $\begin{array}{l}13 \% \\
\text { maximum }\end{array}$ & $\begin{array}{l}70 \% \\
\text { minimum }\end{array}$ & $\begin{array}{l}3 \% \\
\text { maximum }\end{array}$ & $\begin{array}{l}2 \% \\
\text { maximum }\end{array}$ & - & - \\
\hline $\begin{array}{l}\text { Cassava meal } \\
\text { From } \\
\text { Experiment } 8\end{array}$ & $8.78 \%$ & $82.37 \%$ & $1.29 \%$ & $1.54 \%$ & $1.97 \%$ & $0.67 \%$ \\
\hline
\end{tabular}

Table 6.S/N responses to swelling index of dried cassava meal

\begin{tabular}{|c|c|c|c|c|c|c|c|}
\hline \multirow{2}{*}{$\begin{array}{l}\text { CRD } \\
\text { Parameter }\end{array}$} & \multirow[t]{2}{*}{ Symbol } & \multicolumn{2}{|c|}{ Average S/N Ratio } & \multirow{2}{*}{$\begin{array}{l}\text { Parameter } \\
\text { Average }\end{array}$} & \multirow{2}{*}{$\begin{array}{l}\text { Grand } \\
\text { Mean }\end{array}$} & \multirow{2}{*}{$\begin{array}{l}\text { Difference } \\
\text { of } S / N\end{array}$} & \multirow[t]{2}{*}{ Ranking } \\
\hline & & Level 1 & Level 2 & & & & \\
\hline $\begin{array}{l}\text { Shape of } \\
\text { flight }\end{array}$ & A & $\begin{array}{l}-4.92 \\
1.89\end{array}$ & $\begin{array}{l}-4.90^{\mathrm{a}} \\
1.77^{\mathrm{b}}\end{array}$ & $\begin{array}{l}-4.91 \\
1.83\end{array}$ & & 0.02 & $4^{\mathrm{th}}$ \\
\hline $\begin{array}{l}\text { Batch } \\
\text { quantity }\end{array}$ & B & $\begin{array}{l}-6.17 \\
2.09\end{array}$ & $\begin{array}{l}-3.65^{\mathrm{a}} \\
1.57^{\mathrm{b}}\end{array}$ & $\begin{array}{l}-4.91 \\
1.83\end{array}$ & $\begin{array}{l}\mathrm{S} / \mathrm{N}: \\
-4.91\end{array}$ & 2.52 & $2^{\text {nd }}$ \\
\hline $\begin{array}{l}\text { Vapor } \\
\text { extraction }\end{array}$ & $\mathrm{C}$ & $\begin{array}{l}-5.70 \\
1.99\end{array}$ & $\begin{array}{l}-4.12^{\mathrm{a}} \\
1.67^{\mathrm{b}}\end{array}$ & $\begin{array}{l}-4.91 \\
1.83\end{array}$ & $\begin{array}{l}\text { SI: } \\
1.83\end{array}$ & 1.58 & $3^{\text {rd }}$ \\
\hline $\begin{array}{l}\text { Drum } \\
\text { temperature }\end{array}$ & $\mathrm{D}$ & $\begin{array}{l}-3.33^{\mathrm{a}} \\
1.50^{\mathrm{b}}\end{array}$ & $\begin{array}{l}-6.49 \\
2.15\end{array}$ & $\begin{array}{l}-4.91 \\
1.83\end{array}$ & & 3.16 & $1^{\text {st }}$ \\
\hline
\end{tabular}

${ }^{a}$ Higher value of $S / N$ ratio indicate the optimum level of each parameter: $A_{2} B_{2} C_{2} D_{1}$

${ }^{b}$ Corresponding values of swelling index of at optimum levels of each parameter

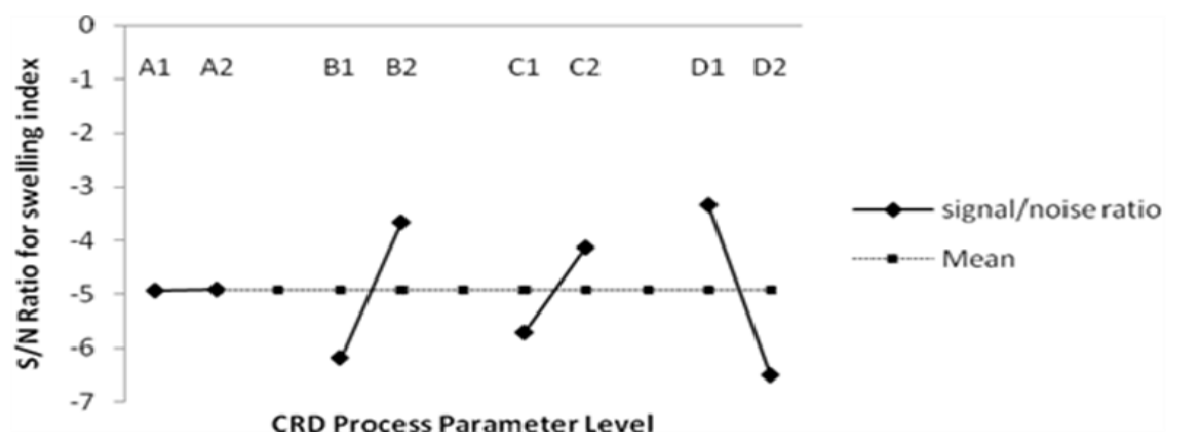

Figure 2. Effects of CRD parameters on the swelling index of dried cassava flour $A_{1}$ and $A_{2}: S / N$ ratio of swelling index for the use of straight and curved flight respectively $B_{1}$ and $B_{2}$ : S/N ratio of swelling index at batch quantity of $5 \mathrm{~kg}$ and $8 \mathrm{~kg}$ respectively

$\mathrm{C}_{1}$ and $\mathrm{C}_{2}$ : S/N ratio of swelling index at vapor extraction rate of $0.0075 \mathrm{~m}^{3} / \mathrm{s}$ and $0.03 \mathrm{~m}^{3} / \mathrm{s}$ respectively

$\mathrm{D} 1$ and D2: S/N ratio of swelling index at drum temperature of $140^{\circ} \mathrm{C}$ and $190^{\circ} \mathrm{C}$ respectively

of cassava meal dried in the CRD compared favorably with the SON (2004) standard for cassava flour. The S/N ratio analysis and the corresponding values of swelling index for the two levels of each parameter are presented in Table 6.

The difference between the high and low $\mathrm{S} / \mathrm{N}$ ratios for each parameter indicatesthe effect of the parameter on the swelling index of the dried cassava meal.As shown in
Table 6, the differences in $\mathrm{S} / \mathrm{N}$ ratio in descending order for drum temperature, batch quantity, vapor extraction rate and shape of flight are 3.16, 2.52, 1.58 and 0.02 respectively. The ranking in the last column of Table 6 shows that drum temperature had the greatest effect on the performance of the CRD,therefore a small change in the drum temperature will have significant effect on the swelling index of cassava meal with at least $99 \%$ 
Lateef et al. 191

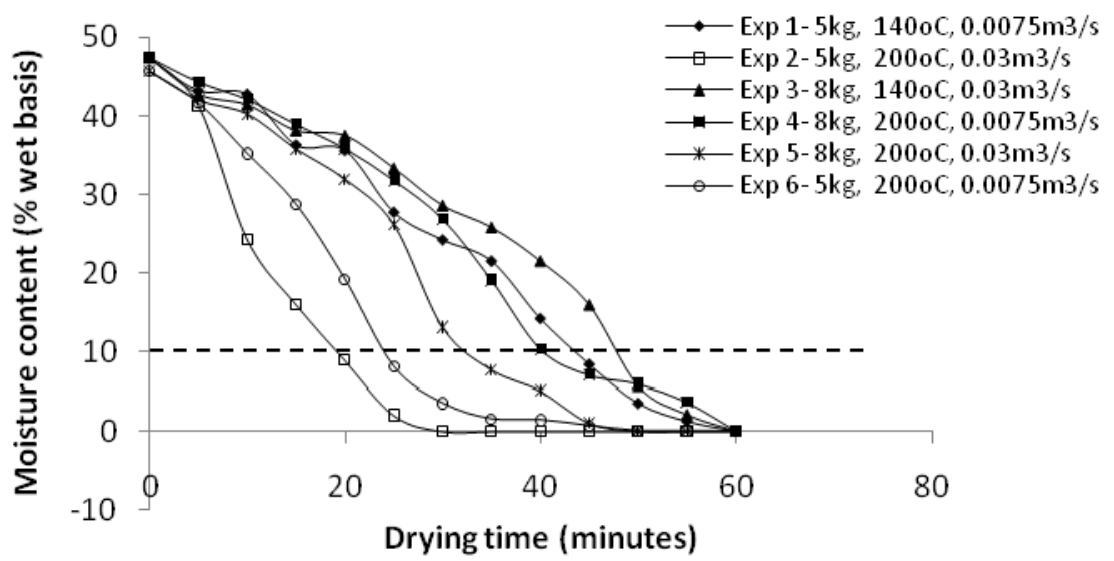

Figure 3. Drying curves of cassava meal under different drying conditions

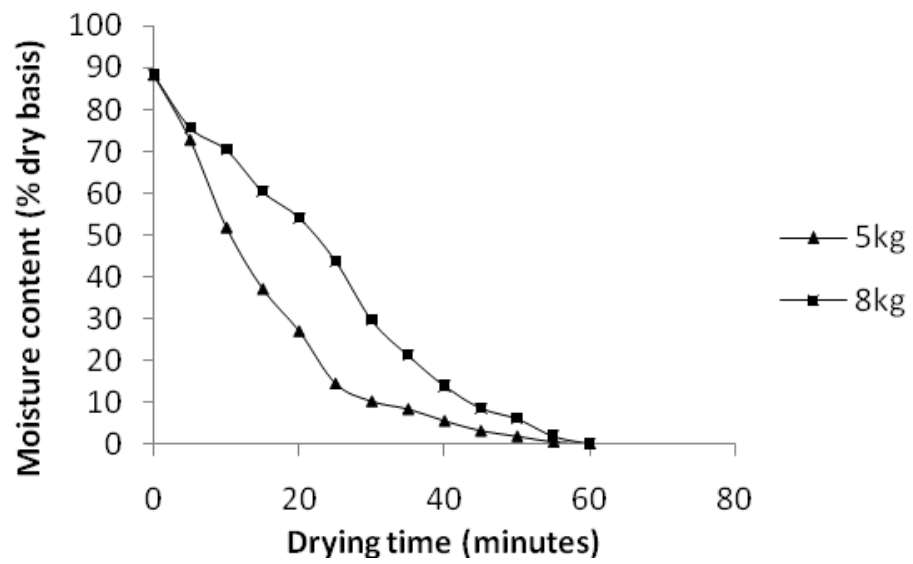

Figure 4. Effect of batch quantity level on drying kinetics of cassava meal

confidence. The shape of flight had very little effect (S/N difference $=0.02$ ), indicating that the shape of flight used did not really matter. A straight flight which is cheaper to produce can therefore be used in place of the curved flight, thereby reducing the cost of the dryer. However the $\mathrm{S} / \mathrm{N}$ ratio analysis shows that the optimum levels at which the CRD parameters should be used for best performance is curved flight $\left(A_{2}\right)$, higher batch quantity of $8 \mathrm{~kg}$ of cassava meal $\left(B_{2}\right)$, higher vapor extraction rate of $0.03 \mathrm{~m}^{3} / \mathrm{s}\left(C_{2}\right)$ but lower drum temperature of $140^{\circ} \mathrm{C}\left(D_{1}\right)$. The graphical illustration in Figure 2 shows the main effects more clearly.

Figure 2 shows that batch quantity of $8 \mathrm{~kg}$, vapor extraction rate of $0.03 \mathrm{~m}^{3} / \mathrm{s}$ and drum temperature of $140^{\circ} \mathrm{C}$ arethe optimaloperating levels at which the CRD should be operated for producing dried cassava meal with a swelling index appropriate for HQCF production. TheS/N ratio line for shape of flight did not deviate from the mean significantly, meaning that shape of flight did not significantly affect the swelling index of cassava mealin the CRD.The analysis of variance (ANOVA)in Table 7 confirmed the signal-to-noise ratio analysis.Drum temperature and batch quantity had significant effects with F-values of 7.22 and 4.22 respectively at $99 \%$ confidence. The contributions of each parameter to the performance of the dryer in order of strength are $42.89 \%$ from drum temperature, $27.46 \%$ from batch quantity, $10.41 \%$ from vapor extraction rate and only $1.47 \%$ from flight shape.

By substituting the values of swelling indexat optimum levels (from Table 6) into Equation 2, a swelling index of 1.02 was predicted. The predicted swelling index of 1.02 is closer to unity than all the values in Table 6 meaning that operating the CRD at the optimum levels of the four parameters will produce dried cassava meal with very low swelling index good enough for HQCF production. The CRD parameters were therefore optimized.

The drying curves which were generated from the moisture contents of the six fractional factorial 
192 Afr. J. Food Sci. Technol.

Table 7. Result of ANOVA on the swelling index of gari

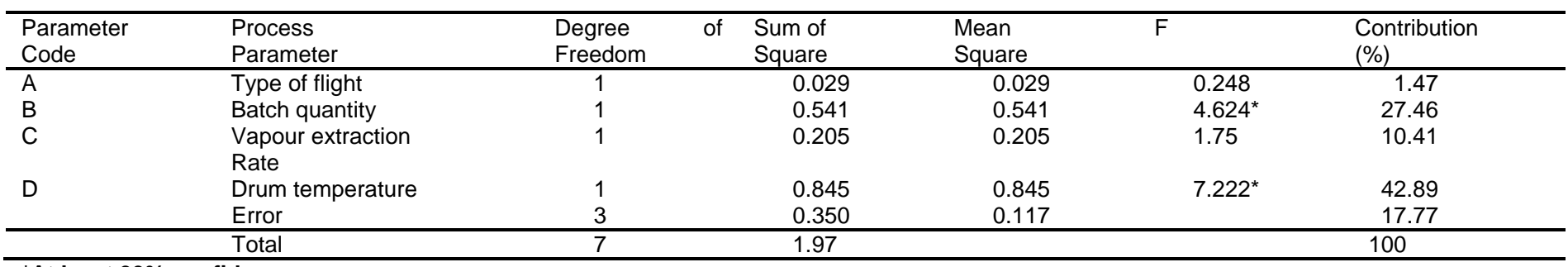

${ }^{*}$ At least $99 \%$ confidence

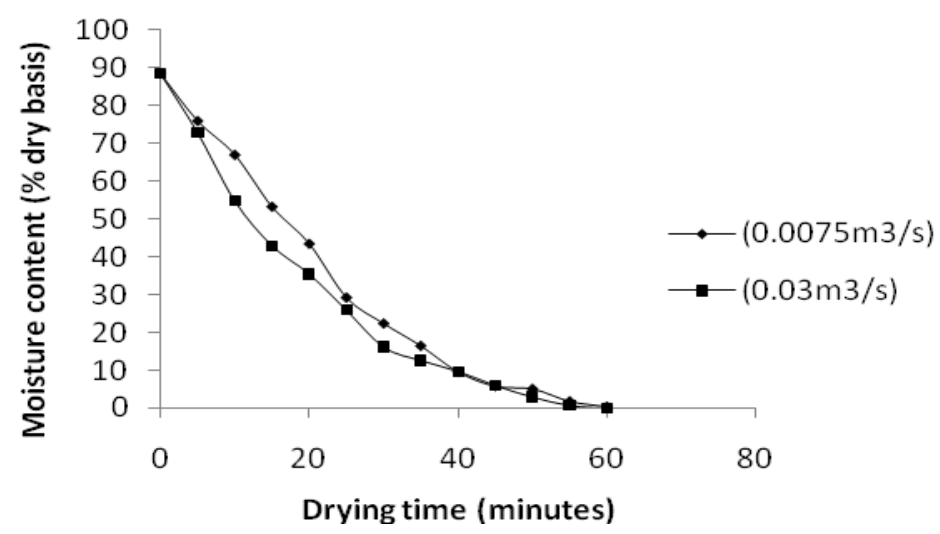

Figure 5. Effect of vapor extraction rate level on drying kinetics of cassava meal

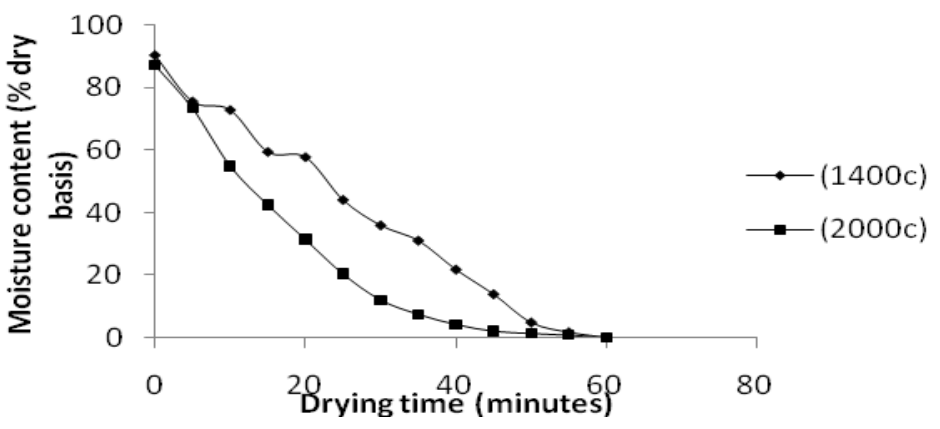

Figure 6. Effect of drum temperature level on drying kinetics of cassava meal

experiments of Table 3are shown in Figure 3. The legend of the graph shows the experiment numbers and their respective levels of the three parameters.

The swelling indices of the cassava meal which were determined after 50 minutes of drying in the CRD were 1.75, 2.36, 1.78, 1.94, 2.19 and 3.22 for Experiments 1, $2,3,4,5$ and 6 respectively. The time at which each batch of cassava meal reached moisture content of $10 \%$ (wet basis), can be read off at the intersection between each drying curve and the $10 \%$ benchmark line. The drying curves of Experiments 1,3 and 4 are more linear and produced cassava meals with lower values of swelling indices (1.75, 1.78 and 1.94 respectively) and were good for HQCF production. The time taken for them to reach the recommended $10 \%$ moisture content were longer, ranging from $40-48$ minutes. The products of Experiments 2, 5 and 6 had higher values of swelling indices (2.36, 2.19 and 3.22 respectively) indicating that they were more gelatinized and were not suitable for HQCF production.

The hysteretic effects of batch quantity, vapor extraction rate and drum temperature on the drying characteristics of the cassava meal in the CRD are presented in the graphs of Figures 4, 5 and 6.

The graphs show that the drying rate of cassava meal in the CRD increased with increase in vapor extraction rate and drum temperature but decreased with increase cc in cc batch quantity. This explains why 
Experiments 1, 3 and 4 took longer drying times but produced better quality cassava meals. The hysteretic relationship between the lower and higher values of each parameter confirms that drum temperature had the greatest effect on the performance of the CRD and the quality of cassava meal produced. Batch quantity had greater effect on the drying rate of the cassava meal than vapor extraction rate.

\section{CONCLUSION}

The study shows that the conductive rotary dryer was capable of drying wet cassava meal for the production of high quality cassava flour. The analysis of the results helped to optimize the operation of the conductive rotary dryer thus improving the drying process through minimum number of experiments. The development and application of the conductive rotary dryer removed the problems associated with traditional sun drying method and produced dried cassava meal which met standard specification. Use of the dryerpromises to increase the production capacity of local cassava processors and itsinjection into the cassava processing industry will contribute to agro-industrial growth in Nigeria and other cassava producing African countries.

\section{REFERENCES}

Ademiluyi FT, Abowei MFN, Puyate YT, Achinewhu SC (2010).Effects of drying parameters on the drying kinetics of fermented ground cassava using a rotary dryer.International Journal of Food Engineering. 6(6): Article 14.

Ajibola OO,Ajayi OA,Faborode M.O,Akanbi CT,Taiwo KA,Adeloye K,Jeje JO,Owolarafe OK, Osunbitan O,Sanni LA,Sunmonu O (1998).Capacity and Agro-processing Technology Needs of Women in Osun and Ondo States of Nigeria.UNDP Survey Report.

AjibolaOO,Ige MT,Makanjuola GA (1987). A preliminary study of a new technique of cassava mash gelatinization. Journal of Agricultural Engineering Research.36: 97-100.

Akhyar G, CheHaron CH,Ghani JA (2008). Application of Taguchi Method in the Optimization of Turning Parameters for Surface Roughness. International Journal of Science Engineering and Technology. Vol. 1, No. 3. Pp. $60-66$.

AOAC (1987). Official methods of analysis of the Association of Official Analytical Chemists.13 ${ }^{\text {th }}$ Edition.Washington D.C. P1094. USA.

Apea-Bah FB,Oduro I, Ellis WO,Safo-Kantanka O(2009). Principal components analysis and age at harvest effect on quality of gari from four elite cassava varieties in Ghana. African Journal of Biotechnology. Vol. 8 (9), Pp 1943-1949.

ASAE (1983).ASAE Standard.S352.1.Moisture Measurement-grain and seeds. $29^{\text {th }}$ Edition. St. Joseph, MI, USA.

Babatunde J(2012). Reviving Nigeria's Economy through Cassava Plan. Report attributed to Minister for Agriculture, Dr. AkinwumiAdesina. Vanguard Newspaper. January 6, 2012.

CIGR (1999). Handbook of Agro-processing Engineering.Volume IV.American Society for Agricultural Engineers. USA.

Cock JH (1985). Cassava: New potential for a neglected crop. Westview Press, Boulder, Colorado, USA

Dziedzoave NT, Abass, AB, Amao-Awua WKA,Sablah M (2006). Quality Management Manual for Production of High Quality Cassava Flour.International Institute of Tropical Agriculture, Ibadan, Nigeria.
Esme U (2009).Application of Taguchi Method for the Optimization of Residual Spot Welding Process.The Arabian Journal for Science and Engineering.34(28): 519-528.

FAO(2000). The Global Cassava Development Strategy and Implementation Plan.Proceedings of the validation forum on the global cassava development strategy.Volume I. Rome.

FAO (2004). A Cassava Industrial Revolution in Nigeria: The potential for a new industrial crop. Rome, Italy.

FAO (2006).Bankable Investment Project Profile. Vol. IV: Cassava Production, Processing and Marketing Project. Food and Agriculture Organization of the United Nations. Rome.

Igbeka JC (1995). Recent developments in cassava frying operation and equipments used for gari production in Nigeria. Transformation Allmentaire du Manioc.ORSTOM.

IITA (2005). Integrated Cassava Project: High quality cassava flour. IITA, Ibadan, Nigeria.

Irtwange SV,Achimba O (2009). Effect of the Duration of Fermentation on the Quality of Gari.Current Research Journal of Biological Sciences 1(3): 150-154.

Mujumdar AS (2006).Principles, Classification and Selection of Dryers. In: Handbook of Industrial Drying. Taylor and Francis Group.LLC.

Kamaruddin S, Khan AZ, Wan KS (2004). The Use of Taguchi Method in Determining the Optimum Plastic Injection Moulding Parameters for the Production of a Consumer Product.JurnalMekanikal. Bil.18, 98 110.

Nweke FI, Spencer DSC,Lynam JK (2002). The cassava transformation: Africa's best kept secret. Michigan State University Press, East Lansing, USA. Pp. $7-206$.

Oluwole OB, Olatunji OO,Odunfa SA (2004). A process technology for conversion of dried cassava chips into garri. Nigerian Food Journal.22: $65-73$.

Owuamanam Cl, Ogueke CC, Achinewhu SC,Barimalaa IS (2010). Quality Characteristics of Gari as Affected by Preferment Liquor, Temperature and Duration of Fermentation. American Journal of Food Technology, 6: 374-384.

Phillips TP, Taylor DS,Sanni L,Akoroda MO (2004). A cassava industrial revolution in Nigeria: The potential for a new industrial crop. IITA, IFAD and FAO. Rome, Italy.

Sanni LA (2014). Studies on conductive rotary drying for industrial cassava processing. Ph.D. Thesis. Department of Agricultural and Environmental Engineering.ObafemiAwolowo University, II-Ife, Nigeria.

Sanni LA, Odukogbe OO, Faborode MO, Ibrahim RO (2015). Optimization of process parameters of a conductive rotary dryer for gari production.Proceedings of International Conference on National Capacity Building Strategy for Sustainable Development and Poverty Alleviation. 26 - 28 May 2015. Cr1006, Block 10, The American University in the Emirates, Dubai, UAE. 527-532.

Sanni LO, Onadipe OO, Ilona P, Mussagy MD, Abass A, Dixon AGO (2009). Successes and Challenges of Cassava Enterprise in West Africa: A case study of Nigeria, Benin and Sierra Leone. International Institute of Tropical Agriculture, Ibadan, Nigeria. Pp 911.

Standard Organization of Nigeria (2004).Standard for Edible Cassava Flour.Nigerian Industrial Standards.No. 344. Lagos, Nigeria.

Udofia PG, Uduodo PJ, Eyen NO,Udoekong NS (2010). Optimizing gari quality attributes for different groups of consumers with response surface methodology. Journal of Agricultural Biotechnology and Sustainable Development. 3(2): Pp 28 - 34. 